\title{
Connectivity and trade relativity: the case of ASEAN
}

\author{
Y. H. Venus Lun ${ }^{1 *}$ and Jan Hoffmann ${ }^{2}$
}

\author{
* Correspondence: \\ venus.lun@polyu.edu.hk \\ 'Shipping Research Centre, The \\ Hong Kong Polytechnic University, \\ Hong kong, Hong kong \\ Full list of author information is \\ available at the end of the article
}

\begin{abstract}
To explore the concept of connectivity and trade relativity (CTR), this paper presents a research model to illustrate: (1) the impact of shipping connectivity on two types of trade flows, and (2) the mediating effect of intra-regional trade ("intra-trade") on the relationship between shipping connectivity and extra-regional trade ("extra-trade"). Understanding the relationships among shipping connectivity and the two types of trade flows (intra-trade and extra-trade) provides insights for managers to make their location decision and identify countries with appropriate levels of shipping connectivity to conduct their trading related activities, and for policy makers to develop measures to enhance trade competitiveness and shipping connectivity. This study also contributes to the concepts of trade creation and trade diversion through the examination of shipping connectivity. A regional trade agreement such as the Association of Southeast Asian Nations (ASEAN) leads to more intra-trade. Some of this trade is new (trade creation) and some might substitute for extra-trade (trade diversion). By incorporating shipping connectivity into the analysis, we show that the trade diversion effect will be reduced thanks to the overall increased shipping connectivity, as the latter will not only benefit intra-trade but also extra-trade.
\end{abstract}

\section{Introduction}

Studies on shipping connectivity and trade facilitation have received increased attention. One of the areas of interest is the emerging array of preferential trading arrangements. The development in regional integration over the past decades has contributed to the expansion of intra-regional trade ("intra-trade"), including through reductions in tariff rates among the member countries. As international trade flows (i.e. the demand for transport services) and shipping (i.e. the supply of maritime transport services) are highly related, it is of interest to examine the relationship between shipping connectivity and international trade ("shipping connectivity and trade relativity" (CTR)). The concept of CTR is important for the development of regional integration. The aim of using CTR is to examine the relationship between connectivity and trade volume. Nevertheless, the existing literature has not examined this concept in much detail, and the present paper aims to make an initial contribution, as well as raise a number of follow-up questions to encourage further research.

The focus in the existing literature is on: (1) the effects of the formation of free trade agreements, which implies differential treatment for member countries, i.e., "trade creation" which results from the formation of a free trade region, and (2) "trade 
diversion", which is trade diverted through free trade agreements, with the use of general equilibrium frameworks for simultaneous equilibrium of all markets in the international economy. However, there is a paucity of empirical research that incorporates the role of transport services supply into the discussion. It is therefore essential to build a theory to examine the impact of shipping connectivity on two types of trade flows (intra-trade and extra-trade) in the era of regional integration. The influential role of intra-trade on the development of shipping connectivity and its impact on extra-trade are also important issues that warrant investigation.

In examining CTR, the essential variables are shipping connectivity, intra-trade and extra-trade:

- Shipping connectivity: Logistics and transport inefficiencies negatively affect trading activities because they result in longer voyage times and higher costs in handling and delivering goods. While tariff-based trade barriers are being reduced within multilateral agreements and the development of trading blocs, the contribution of shipping connectivity to the flow of intra trade and extra trade is a pending concern that merits further attention.

- Intra-trade: Free trade agreements are one of the most common schemes of economic integration. When countries take part in a free trade agreement, they are required to remove or reduce tariff-based barriers. Increasingly, free trade agreements also incorporate aspects of trade facilitation (e.g., single window customs clearance). With the existence of a free trade agreement, trading among member countries (i.e. intra-trade) is expected to increase.

- Extra-trade: A beneficial spillover effect occurs through the enhancement of shipping connectivity from intra-trade growth. The development in shipping connectivity that results from growing regional integration can promote trade flow beyond member countries (i.e. extra-trade).

This study aims to make two contributions to advance the literature on shipping connectivity and international trade (Hausman 2004; Hausman et al. 2013; Hummels 2007; Kumar and Hoffmann 2002). First, it extends the focus of previous studies which have only examined the effect of logistics on international trade to examining the impact of shipping connectivity on two types of trade flows. Second, it emphasizes the role of shipping connectivity in promoting international trade by suggesting that the formation of free trade areas will not only promote trade between the member countries (i.e., intra-trade) but also increase member trade with the rest of the world (i.e., extra-trade). This study provides insights on the concepts of trade creation and trade diversion (Viner 1950 and Balassa 1967).

The trade creation effect occurs when the formation of a free trade agreement encourages intra-trade. Grounded on Head and Ries (1998) trade creation can be defined as the increase in international trade volume from joining a free trade agreement. The trade diversion effect is reduced when intra-trade creates a mediating effect through the positive influence of shipping connectivity on extra-trade. From the practical managerial and policy perspectives, understanding the relationships among shipping connectivity and intra-trade and extra-trade trade flows is important. For instance, it may provide insights for business managers to make location decisions and identify 
countries with appropriate levels of shipping connectivity, and policy makers to develop measures that enhance shipping connectivity. The objectives of this study are therefore to explore the concept of CTR and build a research model to illustrate: (1) the impact of shipping connectivity on the two types of trade flows, and (2) the mediating effect of intra-trade in governing the relationship between shipping connectivity and extra-trade. We use the data of the Association of Southeast Asian Nations (ASEAN) to illustrate CTR and the mediating effect of intra-trade.

\section{Conceptualization}

Topics of economic integration and free trade agreements are important to global trade (Karakaya and Ozgen 2002; Hew 2008; Sun and Reed 2010). In the past decades, a number of trading blocs have been established across Asia, the Americas, Australia, Africa and Europe. Examples of trading blocs include the Asia-Pacific Economic Cooperation (APEC), European Free Trade Association (EFTA), and the East African Community (EAC). These trading blocs have formulated free trade agreements to reduce or eliminate tariffs among the member countries. Free trade agreements are a cooperative arrangement among the members of a trading bloc for regional integration and to enhance the competiveness of the member countries (Wonnacott 1996). A typical example of a regional integration effort is ASEAN, which is being transformed into an institutionalized economic bloc (Subhash and Soo 2000; Narine 2003). The availability of shipping services is an important factor that affects trade costs and trade flows (United Nations ECLAC 2002, Hummels 2007, Sourdin and Pomfret 2012, Wilmsmeier 2014). Shipping and logistics service need to be developed in parallel with international trade demands to realize regional economic integration (Banomyong et al. 2008; Narine 2003). Since shipping services facilitate international trade, trade flows are positively correlated with shipping connectivity. Connectivity among trading partners improves as the trading bloc develops.

\section{Shipping connectivity}

Generally speaking, international trade barriers are tariff based and non-tariff based. Free trade agreements mainly address tariff based barriers. A number of previous studies have suggested that it is also important to examine the impacts of non-tariff-based barriers on international trade flow (Limao and Venables 2001; Hummels 2007). Examples of issues that could lead to non-tariff barriers include logistics efficiency and shipping connectivity (Wilson et al. 2004; Brooks 2010; Appleyard et al. 2001). Shipping that focuses on maritime transport continues to be the most important mode for international trade of goods, and most trade in manufactured goods is containerized and transported via regular liner shipping services (UNCTAD 2015). Shipping connectivity is associated with the competiveness of a region in performing trading activities (Djankov et al., 2010; Evans and Harrigan, 2005; Hausman et al., 2013; Hummels and Schaur, 2013; Nordas et al., 2006, Hausman 2004; Carruthers et al., 2004; Nordas et al., 2006). The efficiency of logistics operations and level of the shipping connectivity have a lead role in affecting trade flow (Yu et al. 2015; Wilmsmeier et al 2006; Wilmsmeier and Hoffmann 2008; Arvis et al. 2013, Fugazza 2015). Characteristics of economies with excellent shipping connectivity include: (1) a large number of ships calling the 
ports, (2) high throughput, (3) a large number of shipping companies that provide shipping services, (4) comprehensive range of liner shipping services, and (5) an infrastructure that is capable of handling mega ships. In ASEAN, the country with the highest level of shipping connectivity as captured by the liner shipping connectivity index (LSCI) is Singapore, followed by Malaysia. In both countries, the LSCI is not only influenced by demand which is considered from the trade of the respective countries, but also by demand for transshipment services (Fig. 1).

\section{Intra-trade}

Free trade agreements are a common means for economic integration which would enhance regional competitiveness (Krugman 2015). Entering into a free trade agreement means that the members of a trading bloc cooperatively eliminate or reduce tariffs on trade with member countries to increase trade flow (Appleyard et al. 2001). In addition to tariffs, other preferential trading arrangements (e.g., customs unions) are also part of free trade agreements (Krueger 1997). The implementation of free trade agreements that allow for different treatment between the member and non-member countries result in trade creation and trade diversion effects (Clausing 2003). As free trade agreements remove or reduce tariff-based barriers, economic integration therefore promotes intra-trade which allows member countries of trading blocs to increase their market size and enhance their production efficiency (Lim 2009, Lee and Lee 2012). With member countries performing trading activities among themselves in a trading bloc, economic regionalism thus contributes to the development of trade protectionism (Lim 2009; Schiff and Winters 2003; Ruggie 1994). Nevertheless, there are a number of benefits in the formation of free trade agreements that are related to increases in overall trade volume. These benefits include: (1) the reduction or removal of tariffs, which contributes to reduced total costs of importing goods (Eaton and Kortum 2003), (2) new inflows of goods from member countries due to trading of cheaper goods (Schiff and

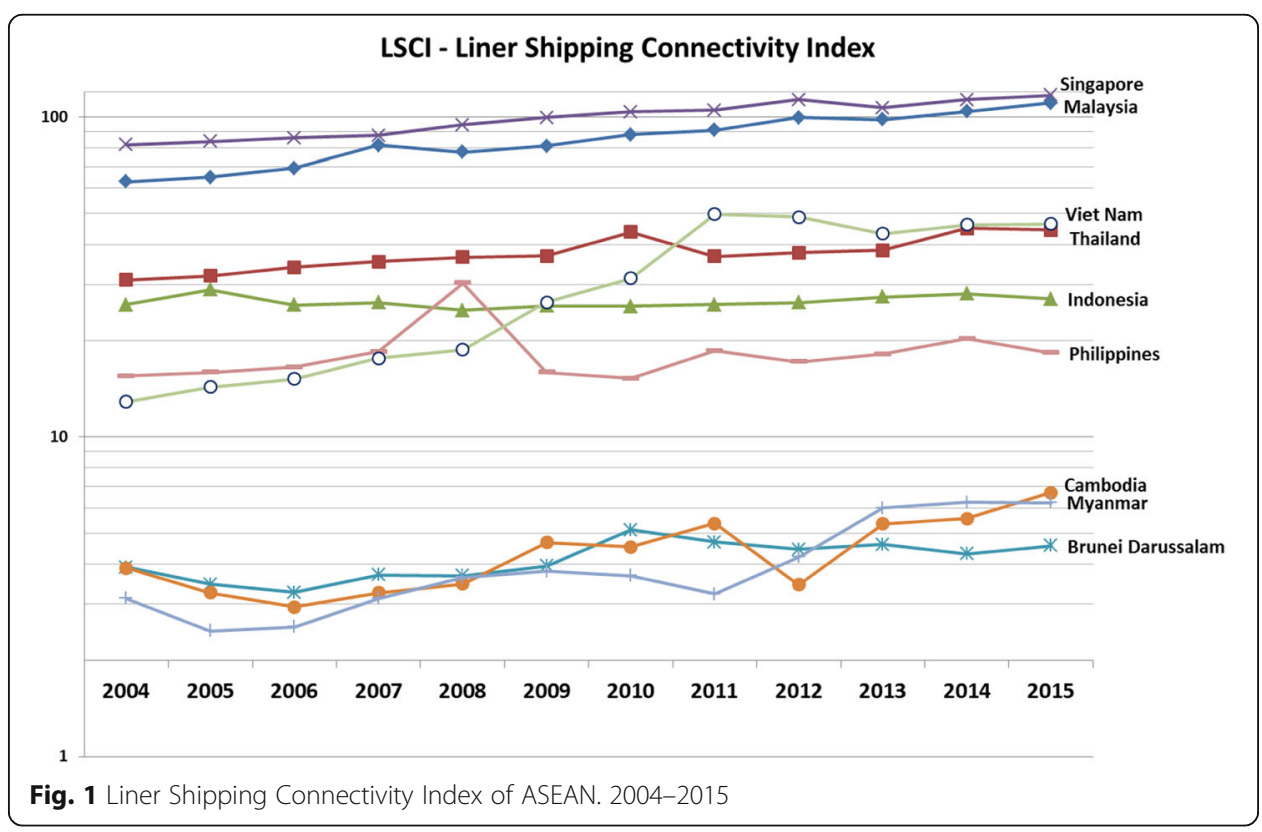


Winters 2003), and (3) improvement in production, consumption, international investment flow, GDP and welfare (Hertel et al. 2001).

\section{Extra-trade}

As free trade agreements remove or reduce tariff-based barriers, the integration of economies to promote intra-trade allows member countries of trading blocs to increase their market size and enhance their production efficiency (Lim 2009, Lee and Lee 2012). To examine trade flow, it is important to explore the impacts of free trade agreements on trade creation and trade diversion (Sun and Reed 2010). There is the general consensus that the trade creation effect is important to generate intra-trade. In terms of trade diversion, the member countries divert the inflow of goods from non-member countries with free trade agreements (Balassa 1967; Richardon 1993). However, the effect of trade diversion negatively affects the volume of extra-trade beyond the member countries who have signed free trade agreements. On the other hand, the increase in the volume of intra-trade improves shipping connectivity. With improvements in the shipping connectivity, both intra-trade and extra-trade can be more efficiently carried out.

\section{Research model}

The effects of trade creation and trade diversion due to the development of a trading bloc are extensively discussed in various contexts (Endoh 1999; Pelzman 1977; Wylie 1995). Trade creation occurs when the enactment of a free trade agreement enables the member countries to import goods at a lower cost from other member countries due to tariff elimination or reduction. Hence, the volume of intra-trade is generally increased with the enactment of free trade agreements. From the perspective of exporting countries, the increase in intra-trade flow will improve the economies of scale in production. Overall efficiency will be improved not only in the production efficiency but also shipping connectivity and other trade facilitation arrangements (e.g., capital flow and customs clearance) which are essential for transporting goods from importing to exporting countries.

There is a positive linkage between the shipping connectivity of a country and its trading activities. Specifically, enhancement of the shipping connectivity of a country positively influences its trade flow. Shipping connectivity is important for facilitating international trade growth. As free trade agreements reduce the level of trade protection by eliminating tariff-based trade barriers, intra-trade volume is expected to increase with intra-trade agreements. However, limited shipping connectivity is a form of a non-tariff barrier in moving goods from an exporting to importing area. Improvements in shipping connectivity eliminate one of the most important non-tariff trade barriers so that countries can more efficiently perform trading activities. To promote international trade, both free trade agreements and shipping connectivity are important. With the growth of intra-trade via economic integration, member countries can reap competitive advantages with higher productivity and infrastructure improvements. Improved infrastructures facilitate economic development and enhance shipping connectivity. Hence, the following hypothesis is developed:

Hypothesis 1: Shipping connectivity is positively correlated with intra-trade.

Trade diversion is the replacement of cheaper imports from non-member countries with products of member countries due to a free trade agreement (Balassa 1967; 
Richardon 1993). Trade diversion occurs when free trade agreements among member countries shift the trade inflow from non-number to member countries in a trading bloc to increase the flow of intra-trade. When member countries perform trading activities among themselves in a trading bloc (i.e., intra-trade), this is economic regionalism which contributes to the development of trade protectionism (Lim 2009; Schiff and Winters 2003; Ruggie 1994). Richardon (1993) also pointed out the consequences of trade protection resultant of free trade agreements on non-member countries (extra-trade). Nevertheless, the number of free trade agreements are increasing. It is therefore important to examine the relationship between free trade agreements and extra-trade. Conventional theories on preferential trading have focused on the trade-offs between trade creation on intra-trade and trade diversion on extra-trade. However the role of shipping connectivity in facilitating trade has not been explored in detail. Shipping connectivity of a country involves shipping service coverage and ability of transport infrastructures to support trading activities (Korinek and Sourdin, 2011). Improvements in physical transport infrastructures therefore improve shipping connectivity and enhance accessibility in terms of sailing frequency and shorter transit times (Limao and Venables 2001; Wood et al., 2003). Trade-related infrastructures allow increased linkages with the global supply chain to reach trading partners for both intra-trade and extra-trade. Modern container ports, which have the capability of accommodating larger and more vessels, attract cargo flow from member countries as well as other non-members, and intra-regional shipping services can de facto serve as feedering services which also serve extra-regional trade. Hence, the following hypothesis is developed:

Hypothesis 2: Shipping connectivity is positively correlated with extra-trade.

The effects of trade creation and trade diversion on the development of trading blocs are extensively discussed in various contexts (Endoh 1999; Pelzman 1977; Wylie 1995). International trade is strongly linked to economic development through the mechanisms of capital accumulation, technological change, and human resource accumulation (Lucas 1988). Due to the growth in intra trade, overall efficiency will be improved not only in terms of production but also various trade facilitation activities which are essential for transporting goods from importing to exporting countries. Here, shipping connectivity plays an important role in facilitating trade activities. With the formulation of free trade agreements, international trade now involves intra-trade and extra-trade. Intra-trade is a mediator that governs the relationship between shipping connectivity and extra-trade when the following conditions are met: (1) shipping connectivity affects intra-trade flow, (2) shipping connectivity affects extra-trade, and (3) intra-trade affects extra-trade, and the effect of shipping connectivity (on the third condition) must be smaller than the effect on the second condition (Baron and Kenny 1986). Accordingly, the third hypothesis is developed as follows:

Hypothesis 3: Intra-trade mediates the relationship between shipping connectivity and extra-trade.

Based on this conceptualization, the research model proposes: (1) the concept of CTR, in which shipping connectivity is positively correlated with intra-trade on the one hand and extra-trade on the other hand, and (2) that intra-trade has a mediating effect in governing 


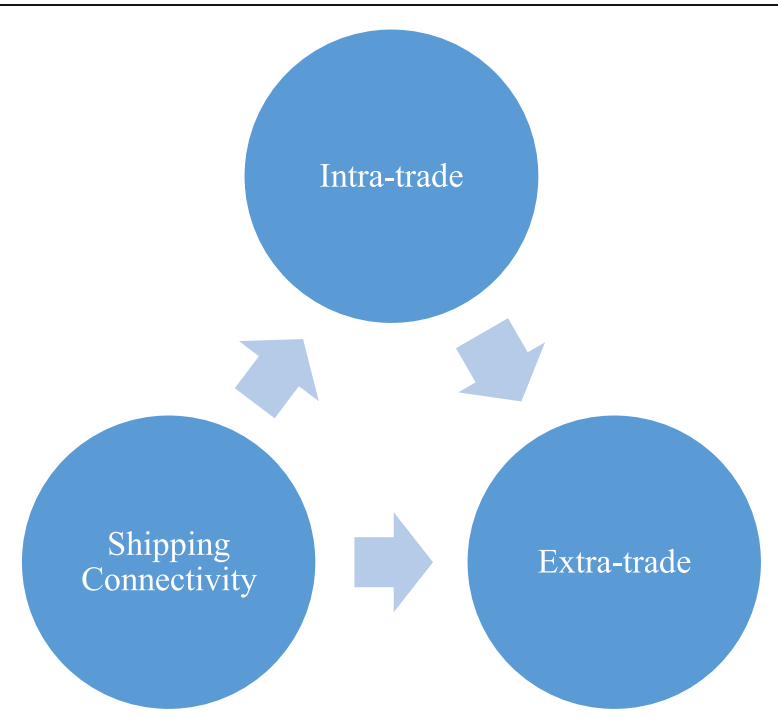

Fig. 2 Relationships among shipping connectivity, intra-trade and extra-trade

the relationship between shipping connectivity and extra-trade. In practice, the causalities will always go on in both directions between all three components shown in Fig. 2. More demand from extra-trade will encourage improved shipping connectivity, and changes in extra-trade will have a bearing on intra-trade. In our study, however, we limit the focus to the following qualifiers:

- More intra-trade will have a positive effect on shipping connectivity and an effect on extra trade through trade creation and trade diversion.

- Improved shipping connectivity will have a positive impact on both intra-trade and extra-trade.

\section{Methodology}

This study uses a multi-method approach to investigate CTR, which involves the use of two or more research methods. To validate the research model, we used a three-step approach:

- correlation and regression analyses were used to examine the relationships among the variables of shipping connectivity, intra-trade and extra-trade,

- CTR was examined with formulated equations, and

- the mediating effect of intra-trade was tested on the relationship between shipping connectivity and extra-trade with three regression equations (Baron and Kenny (1986).

This study uses the case of ASEAN to illustrate the concept of CTR and examine the mediating effect of intra-trade. The ten ASEAN member countries are Brunei, Cambodia, Indonesia, Laos, Malaysia, Myanmar, the Philippines, Singapore, Thailand and Vietnam.

The three variables involved are shipping connectivity and the two types of trade flows (intra-trade and extra-trade) as follows:

- Shipping connectivity was measured by using the LSCI of the United Nations Conference on Trade and Development (UNCTAD). The LSCI of the UNCTAD has five components: (1) the number of container ships, (2) their combined 
container carrying capacity, (3) the number of shipping companies that provide shipping services, (4) the number of liner shipping services, and (5) the size of the largest ship deployed for services to and from the country's seaports. We used 10 years (2005-2014) of data from nine ASEAN countries (Laos is land-locked and not available on the LSCI). The sample size (n) was $9 \times 10$ (i.e., 90). The data for shipping connectivity were collected from UNCTAD stat 2016.

- Intra-ASEAN denotes the trading activities among the ten ASEAN countries. Extra-ASEAN denotes the trading activities of the ten ASEAN countries with trading partners beyond the ASEAN members. The sample size (n) was $10 \times 10$ (i.e., 100). The data of the intra-trade and extra-trade of ASEAN were collected from ASEAN (The intra-trade and extra-trade of ASEAN).

\section{Analysis and results}

\section{Correlation and regression analysis}

The results showed that shipping connectivity, intra-trade and extra-trade are positively correlated. This correlation is complex and a wide range of linkages are behind the simple partial statistical correlation. All three variables are linked to other variables, such as the GDP, the composition of trade (manufactured goods, commodities), or trade balances. Geographical position in the global shipping networks has a role as some countries may provide transshipment services, while the ports of other countries are way ports. These form the basis for a wide range of future research topics.

According to the data from the ten ASEAN countries, shipping connectivity is positively correlated with both intra-trade and extra-trade. As shown in the correlation matrix of Table 1, shipping connectivity is positively correlated with intra-trade (with a correlation coefficient of 0.932) and extra-trade (with a correlation coefficient of 0.896). Intra-trade and extra-trade are also linked (with a correlation coefficient of 0.969). To further investigate the relationship between shipping connectivity and the two types of trade flows, we conducted a regression analysis to predict the trade flow based on shipping connectivity.

The positive relationship between shipping connectivity and intra-trade is shown in (the logarithmic scale is used which allows better visualization).

The results suggest that shipping connectivity affects both intra-trade and extratrade. The two types of trade flows are expected to increase with the enhancement of shipping connectivity. Equations 1 and 2 are used to predict the values of intra-trade and extra-trade based on the level of shipping connectivity.

Based on the regression analysis, the following regression equation is formulated:

$$
t_{i a}=4.61+1.51 s_{a}
$$

Table 1 Correlation matrix of the variables

\begin{tabular}{llll}
\hline & $s_{a}$ & $t_{i a}$ & $t_{e a}$ \\
\hline$s_{a}$ & 1.00 & & \\
$t_{i a}$ & $0.932^{\mathrm{a}}$ & 1.00 & 1.00 \\
$t_{e a}$ & $0.986^{\mathrm{a}}$ & $0.969^{\mathrm{a}}$ &
\end{tabular}


where $t_{i a}$ is the intra-trade of the ASEAN countries and $s_{a}$ is the shipping connectivity index of the ASEAN countries.

The positive relationship between shipping connectivity and extra-trade is illustrated in Equation (2). Based on the regression analysis, the following regression equation is formulated:

$$
t_{e a}=26.72+3.88 s_{a}
$$

where $t_{e a}$ is the extra-trade of the ASEAN countries and $s_{a}$ is the shipping connectivity index of the ASEAN countries.

The results suggest that shipping connectivity affects both intra-trade and extratrade. The two types of trade flows are expected to increase with the enhancement of shipping connectivity. Equations 1 and 2 are used to predict the values of intra-trade and extra-trade based on the level of shipping connectivity.

\section{Connectivity and trade relativity}

Shipping connectivity is linked to intra-trade as shown in the correlation matrix of Table 1 (with a correlation coefficient of 0.932 ). The positive relationship between shipping connectivity and trade flow is shown in Fig. 3.

Hence, shipping connectivity and intra-trade are proportional, i.e.,

$$
s=k_{i} t_{i}
$$

where $k_{i}$ is a constant of $\mathrm{CTR}_{i}>0$, which is defined as the 'relativity between shipping connectivity and intra-trade', and $t_{i}=$ extra-trade

It follows that

$$
k_{i}=s / t_{i}
$$

On the other hand, shipping connectivity is also linked to extra-trade. As shown in the correlation matrix of Table 1, shipping connectivity is linked to extra-trade (with a

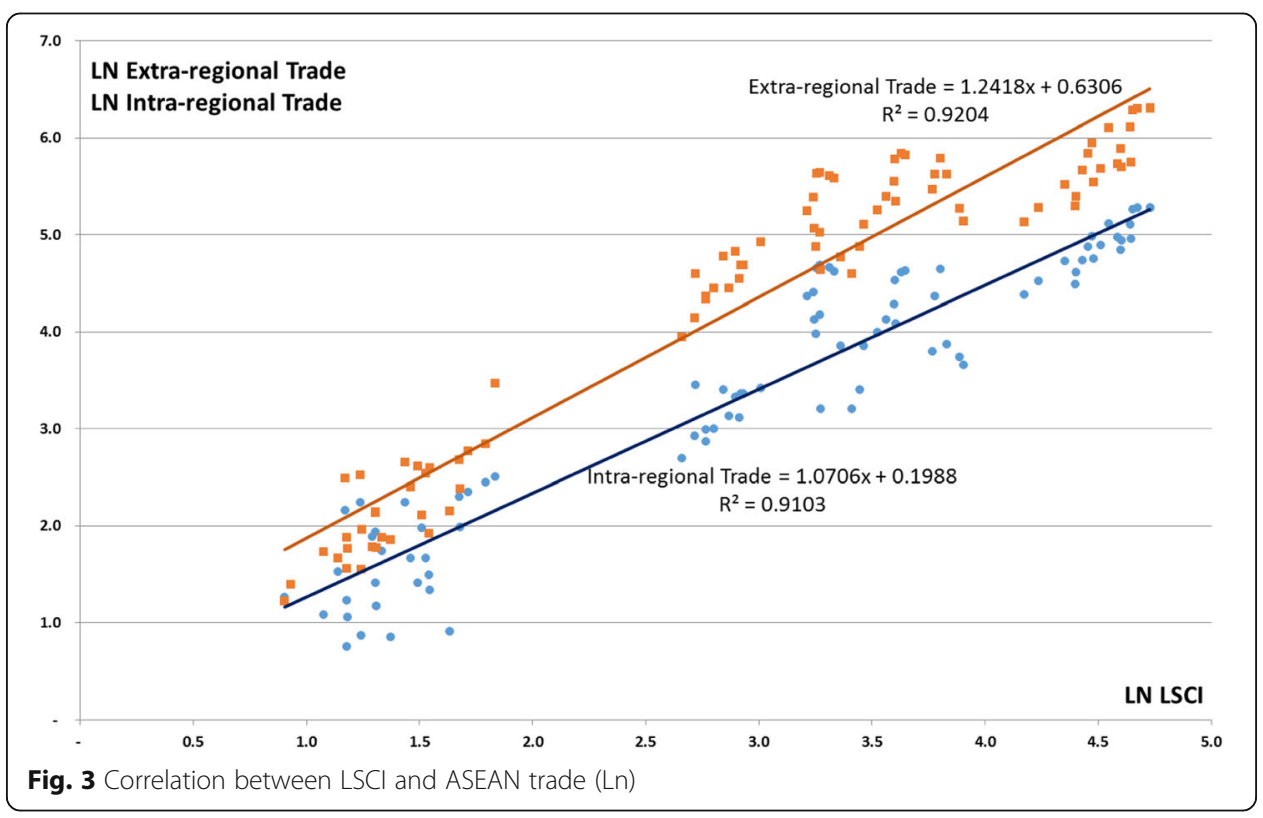


correlation coefficient of 0.986 ). The positive relationship between shipping connectivity and extra-trade is shown in Fig. 3.

Hence, shipping connectivity and extra-trade are also proportional, i.e.,

$$
s=k_{e} t_{e}
$$

where $k_{e}$ is a constant of $\mathrm{CTR}_{\mathrm{e}}>0$, which is defined as the 'relativity between shipping connectivity and extra-trade, and $t_{e}=$ extra-trade.

It follows that

$$
k_{e}=s / t_{e} .
$$

Equation 3 illustrates the positive relationship between shipping connectivity $(s)$ and intra-trade $\left(t_{i}\right)$. Equation 5 illustrates the positive relationship between shipping connectivity $(s)$ and extra-trade $\left(t_{e}\right)$. Equations 4 and 6 show the constant of $\mathrm{CTR}_{i}$ and $\mathrm{CTR}_{\mathrm{e}}$.

To further examine CTR in the case of ASEAN, Equations 1 and 2 are used:

$$
\begin{aligned}
& \text { According to Equation } 1: s_{a}=-3.05+0.66 t_{i a} \\
& \text { According to Equation } 2: s_{a}=-6.89+0.26 t_{e a}
\end{aligned}
$$

By using the empirical data from ASEAN, Equation 7 shows that there is a positive relationship between shipping connectivity $\left(s_{a}\right)$ and intra-trade $\left(t_{i a}\right)$. Equation 8 indicates that there is also a positive relationship between shipping connectivity $\left(s_{a}\right)$ and extra-trade $\left(t_{e a}\right)$. The findings therefore support Hypotheses 1 and 2.

\section{Mediating effect of intra-trade}

The mediating role of intra-trade is also an important part of the research model. Mediating relationships occur when a third variable (i.e., intra-trade) has an important role in governing the relationship between the "independent" and "dependent variables" (i.e., shipping connectivity and extra-trade). As mentioned above, in practice, there are no truly "independent" variables in this relationship; the terms are used only for our model.

A three-step approach proposed by Baron and Kenny (1986) is employed to test the mediating effect of intra-trade that governs the relationship between shipping connectivity and extra-trade: (1) the independent variable must affect the mediator in the first equation; (2) the independent variable must affect the dependent variable in the second equation; and (3) the mediator must affect the dependent variable in the third equation. If all of these conditions hold in the predicted direction, then the effect of the independent variable on the dependent variable must be smaller in the third equation than in the second equation.

To test the mediating effect, the three regression models (as shown in Table 2) were developed based on data on the shipping connectivity, intra-trade and extra-trade in the ten ASEAN countries:

(1) The independent variable $\left(s_{a}\right)$ positively affects the mediator $\left(t_{i a}\right)$ in the first regression model with the regression coefficient of 0.932 at the $p<0.01$ level. The first regression equation is: $t_{i a}=4.61+1.51 s_{a}$ (as shown in Equation 1).

(2) The independent variable $\left(s_{a}\right)$ positively affects the dependent variable $\left(t_{e a}\right)$ in the second regression model with the regression coefficient of 0.986 at the $p<0.01$ 
Table 2 Regression models

\begin{tabular}{llcr}
\hline Model & Path & Regression coefficient & $p$ value \\
\hline 1 & $\mathrm{~S}_{\mathrm{a}} \rightarrow \mathrm{t}_{\mathrm{ia}}$ & 0.932 & $<0.01$ \\
2 & $\mathrm{~S}_{\mathrm{a}} \rightarrow \mathrm{t}_{\text {ea }}$ & 0.986 & $<0.01$ \\
3 & $\mathrm{t}_{\mathrm{ia}} \rightarrow \mathrm{t}_{\mathrm{ea}}$ & 0.969 & $<0.01$ \\
\hline
\end{tabular}

level. The second regression equation is: $t_{e a}=26.72+3.88 s_{a}$ (as shown in Equation 2).

(3) The mediator $\left(t_{i a}\right)$ positively affects the dependent variable $\left(t_{e a}\right)$ in the third regression model with the regression coefficient of 0.969 at the $p<0.01$ level.

Another condition of the three-step approach of Baron and Kenny approach is that: If all of these conditions hold in the predicted direction, then the effect of the independent variable $\left(s_{a}\right)$ must be smaller in the third equation than in the second equation. Therefore, the third regression equation (i.e., Equation 9) which multiple regression equation is formulated by holding the variable of $t_{i a}$ :

$$
t_{e a}=14.08-0.27 s_{a}+2.74 t_{i a}
$$

When all of the conditions hold in the predicted direction, the effect of the independent variable $\left(s_{\mathrm{a}}\right)$ on the dependent variable is smaller in the third equation (i.e.-0.27) than in the second equation (i.e. 3.88). Hence, the mediating effect of intra-trade is established according to the three-step approach proposed by Baron and Kenny. With the data from the ten ASEAN countries, the findings suggest that intra-trade is a mediator that governs the relationship between shipping connectivity and extra-trade. The results support Hypothesis 3.

\section{Conclusions and further research}

This paper has presented a short literature overview and some initial discussion on the relationships among shipping connectivity, intra-trade and extra-trade. Using data from ASEAN, our model suggests that intra-trade can have a positive bearing on shipping connectivity, and the latter can then also have a positive bearing on extra-trade.

The developments in regional integration and free trade agreements over the past decades have led to the expansion of intra-regional trade, thus leading to the development of a number of trading blocs around the world. These trading blocs take the form of regional cooperation in which there is reduction or elimination of tariffs among the member countries. These multinational cooperative arrangements increase the competiveness of their members. Transport, particularly shipping connectivity, is important for facilitating international trade. Therefore, the aim of this study is to contribute to advancing the literature in the areas of shipping connectivity and international trade by: (1) complementing previous studies that have examined the effect of shipping connectivity on trade flow, and (2) exploring the mediating effect of intra-trade on extratrade through its impact on shipping connectivity. Our results indicate that the trade creation effect exists and intra-trade is positively correlated with shipping connectivity. Hence, this study provides empirical evidence to support the trade creation effect. 
The data and considerations in this paper raise a number of questions and suggestions for further research. First, the specific functional form (for example logarithmic scale, linear, other forms), time lags (trade and vessel deployment take time to react to changes in demand and supply patterns) and additional variables need to be taken into account. There is clearly multicollinearity among the "independent" and "dependent" variables that we have used. In addition, the specific data of ASEAN used actually suggest that regional integration has not advanced over the last decade. The share of intratrade in the total trade of a region has slightly decreased over the 10 years covered in this paper. Future research should incorporate additional regional trading blocs. Future research could make use of the data on bilateral connectivity (e.g. LSCI of UNCTAD) in addition to the LSCI at the country level used in this paper. This should explicitly capture intra-regional connectivity versus the connectivity with extra-regional trading partners. In this context, consideration could be given to the share of transshipment, i.e. the role that the ports of a country play within the global liner shipping network.

Authors' contributions

Both authors read and approved the final manuscript.

Competing interests

The authors declare that they have no competing interests.

\section{Author details}

${ }^{1}$ Shipping Research Centre, The Hong Kong Polytechnic University, Hong kong, Hong kong. ${ }^{2}$ United Nations Conference on Trade and Development (UNCTAD), Geneva, Switzerland.

Received: 11 June 2016 Accepted: 12 September 2016

Published online: 03 October 2016

\section{References}

Appleyard DR, Field AJ, Cobb S (2001) International Economics. McGraw-Hill/Irwin, Boston

Arvis JF, Shepherd B, Duval Y, Utoktham C (2013) Trade Costs and Development: A New Data Set. The World Bank, Washington, D.C

Balassa B (1967) Trade creation and trade diversion in the European Common Market. Econ J 77(305):1-21

Banomyong R, Cook P, Kent P (2008) Formulating regional logistics development policy: the case of ASEAN. Int J Log Res Appl 11(5):359-379

Baron RM, Kenny DA (1986) The moderator-mediator variable distinction in social psychological research - conceptual, strategic, and statistical considerations. J Pers Soc Psychol 51(6):1173-1182

Brooks DH (2010) Regional cooperation, infrastructure, and traded costs in Asia. In: Brooks DH, Stone SF (eds) Trade facilitation and regional cooperation in Asia. Edward Elgar, MA, pp 1-22

Carruthers R, Bajpai JN, Hummels D (2004) Trade and logistics: an East Asian perspective. In: Krumm K, Kharas H (eds) East Asia integrates: a trade policy agenda for shared growth. The World Bank and Oxford University Press, Washington D.C., pp 77-94

Clausing KA (2003) Trade creation and trade diversion the Canada-US free trade agreement. Can J Econ 34(3):677-696

Djankov S, Freund C, Pham S (2010) Trading on time. Rev Econ Stat 92(1):166-173

Eaton J, Kortum S (2003) Technology, geography, and trade. Econometrica 70(5):1741-1779

Endoh M (1999) Trade creation and trade diversion in the EEC, the LAFTA and The CMEA. Appl Econ 31(2):207-216

Evans C, Harrigan J (2005) Distance, time, and specialization. Am Econ Rev 95(1):292-313

Fugazza M (2015) Maritime Connectivity and Trade, Policy Issues in International Trade and Commodities Research Studies Series No. 70. UNCTAD, Geneva

Hausman WH (2004) Supply chain performance measures. In: Billington C, Harrison T, Lee H, Neale J (eds) The practice of supply chain management: where theory and application converge. Springer Science \& Media Inc, New York, pp 61-73

Hausman WH, Lee H, Subramanian U (2013) The impact of logistics performance on trade. Prod Oper Manag 22(2):236-253

Head K, Ries J (1998) Immigration and trade creation: Econometric evidence from Canada. Canadian J Economics 31(1):47-62

Hertel TW, Walmsley T, Itakura K (2001) Dynamic effects of the 'new age' free trade agreement between Japan and Singapore. J Economic Integration 16(4):446-484

Hew D (2008) Towards an ASEAN Economic Community by 2015. In: ASEAN Studies Center (eds.) The ASEAN community: unblocking the roadblocks. Institute of Southeast Asian Studies, Singapore, pp 209-224

Hummels D (2007) Transportation costs and international trade in the second era of globalization. J Econ Perspect 21(3):131-154

Hummels D, Schaur G (2013) Time as a trade barrier. Am Econ Rev 103(7):2935-2959

Karakaya E, Ozgen FB (2002) Economic feasibility of Turkey's economic integration with the EU: perspectives from trade creation and trade diversion, Paper presented at the International Economics Research Conference

Korinek J and Sourdin P (2011) To what extent are high-quality logistics services trade facilitating? OECD Trade Policy Papers, No. 108. OECD Publishing. 
Krueger AO (1997) Free trade agreements versus customs unions. J Dev Econ 54(1):169-187

Krugman PR (2015) International Economics: Theory and Policy, 10th edn. Pearson, Boston

Kumar S, Hoffmann J (2002) Globalization: the Maritime Nexus. In: Grammenos CT (ed) Handbook of Maritime Economics and Business. Lloyds List Press, London, pp 35-62

Lee TC, Lee PTW (2012) South-south trade liberalisation and shipping geography: a case study on India, Brazil, and South Africa. Int J Shipping and Transport Logistics 4(4):323-338

Lim CY (2009) Southeast Asia, the Long Road Ahead, 3rd edn. World Scientific Publishing, Singapore

Limao N, Venables A (2001) Infrastructure, geographical disadvantage, transport, costs and trade. World Bank Econ Rev 15(3):451-479

Lucas RE (1988) On the mechanics of economic development. J Monet Econ 22(1):3-42

Narine S (2003) Explaining ASEAN: Regionalism in Southeast Asia. Lynne Rienner Publishers, US

Nordas HK, Pinali E, Geloso Grosso M (2006) Logistics and time as a trade barrier, OECD Trade Policy Working Papers, No. 35. OECD Publishing, Paris

Pelzman J (1977) Trade creation and trade diversion in the Council of Mutual Economic Assistance. Am Econ Rev 67(4) 713-722

Richardon M (1993) Endogenous protection and trade diversion. J Int Econ 34(3):309-324

Ruggie JG (1994) Trade, protectionism and the future of welfare capitalism. J Int Affairs, Contemporary Issues in World Trade 48(1):1-11

Schiff M, Winters LA (2003) Regional Integration and Development. The World Bank, Washington, D.C

Sourdin P, Pomfret R (2012) Trade Facilitation: Defining, Measuring, Explaining and Reducing the Cost of International Trade. Edward Elgar Publishing, Cheltenham

Subhash CS, Soo YC (2000) ASEAN: Economic integration and intra-regional trade. Appl Econ Lett 7(3):165-169

Sun L, Reed M (2010) The impacts of free trade agreements on agricultural trade creation and trade diversion. Am J Agric Econ 92(5):1351-1362

The intra-trade and extra-trade of ASEAN is available on line via http://asean.org/resource/statistics/asean-statistics/.

UNCTAD (2015) Review of Maritime Transport. United Nations Conference on Trade and Development, Geneva

UNCTAD stat (2016) Liner shipping connectivity index, annual, 2004-2016. Available at: http://unctadstat.unctad.org/ wds/TableViewer/tableView.aspx?Reportld=92. Accessed 30 Jan 2016

United Nations ECLAC (2002) El costo del transporte internacional, y la integración y competitividad de América Latina y el Caribe. Boltin FAL 191, Santiago de Chile

Viner J (1950) The Customs Union Issue. Carnegie Endowment, New York

Wilmsmeier G (2014) International Maritime Transport Costs: Market Structures and Network Configurations. Ashgate, Farnham

Wilmsmeier G, Hoffmann J (2008) Liner shipping connectivity and port infrastructure as determinants of freight rates in the Caribbean. Maritime Economics and Logistics 10(1):130-151

Wilmsmeier G, Hoffmann J, Sánchez RJ (2006) The impact of port characteristics on international maritime transport costs. In: Cullinane K, Talley W (eds) Research in Transportation Economics, Volume 16: Port Economics. Elsevier, Amsterdam

Wilson JS, Mann CL, Otsuki T (2004) Assessing the potential benefit of trade facilitation: a global perspective, Working Paper No. 3224. The World Bank, Washington, D.C

Wonnacott RJ (1996) Free-trade agreements: Better or Worse. Am Econ Rev 86(2):62-66

Wood DF, Barone AP, Murphy PR, Wardlow DL (2003) International Logistics. American Management Association, New York

Wylie P (1995) Partial equilibrium estimates of manufacturing trade creation and diversion due to NAFTA. North Am $J$ Econ Finance 6(1):65-84

Yu P, Lai KH, Wong CWY, and Lun YHV (2015) The role logistics in trade facilitation: The lessons from ASEAN. Paper presented at the Conference Booklet of Global Port Research Alliance, Hong Kong

\section{Submit your manuscript to a SpringerOpen ${ }^{\circ}$} journal and benefit from:

- Convenient online submission

- Rigorous peer review

- Immediate publication on acceptance

- Open access: articles freely available online

- High visibility within the field

- Retaining the copyright to your article

Submit your next manuscript at $>$ springeropen.com 